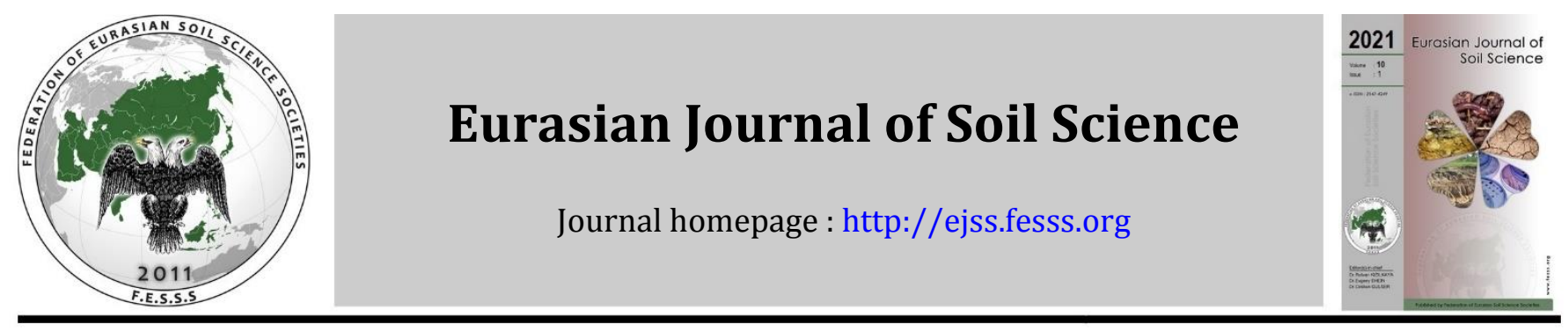

\title{
Reduced plant uptake of PAHs from soil amended with sunflower husk biochar
}

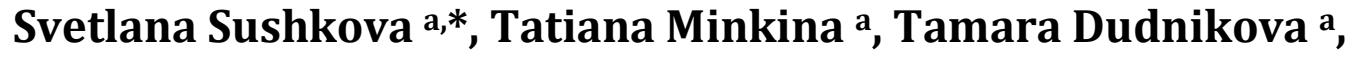 \\ Andrey Barbashev a, Yuryi Popov a, Vishnu Rajput a, Tatiana Bauer a, \\ Olga Nazarenko ${ }^{b}$, Ridvan Kizılkaya ${ }^{c, d}$
}

\footnotetext{
a Southern Federal University, Academy of Biology and Biotechnology D.I. Ivanovsky, Rostov-on-Don, Russia

b Federal State Budgetary Institution State Center of the Agrochemical Service Rostov, Rostov-on-Don, Russia c Ondokuz Mayıs University, Faculty of Agriculture, Department of Soil Science and Plant Nutrition, Samsun, Turkey d Agrobigen Research \& Development Trade Ltd.Co, Samsun Technopark, Samsun, Turkey
}

\section{Article Info}

Received : 19.11.2020

Accepted : 06.05.2021

Available online : 09.05.2021
Author(s)
S. Sushkova *
T. Minkina
T. Dudnikova
A. Barbashev
Y. Popov
V. Rajput
T. Bauer
O. Nazarenko
R. Kızllkaya
* Corresponding author

\begin{abstract}
Biochar effect on the polycyclic aromatic hydrocarbons (PAHs) uptake by spring barley (Hordeum Sativum) was studied in model experiment conditions with Haplic Chernozem spiked by the high doses of benzo[a]pyrene (BaP) (400, 800 and $1200 \mu \mathrm{g} \mathrm{kg}^{-1}$ ), as the main marker of PAHs contamination. The relevance of the study is due to the BaP stability in natural environments and its carcinogenicity in relation to all living organisms. The express method of subcritical water extraction was used for BaP extraction from samples. The soil contamination by BaP contributed to the PAHs accumulation in soil and plants uptake from the polluted soil. It was found the $1 \%$ biochar application dose in the variant with $400 \mu \mathrm{gg}^{-1}$ contamination decreased the alone BaP and total PAHs content in soil and spring barley up to $50 \%$ compared to the contaminated variant. In soil contaminated with $800 \mu \mathrm{g} \mathrm{kg}^{-1}$ the $5 \%$ of biochar application led to the BaP content decreasing in the soil up to $56 \%$ and in the plants to $40-60 \%$. Application of 5\% biochar in the soil polluted with $1200 \mu \mathrm{g}$ $\mathrm{kg}^{-1}$ led to the BaP and total PAHs content decreasing in soil up to $47 \%$ and $30 \%$, respectively, plants the $\mathrm{BaP}$ content decreased up to $37-48 \%$. Biochar $5 \%$ amendment effectiveness has been shown on the plants grown on the highly toxic variant contaminated with $1200 \mu \mathrm{gg}^{-1} \mathrm{BaP}$. The earing phase was inhibited in the spring barley plants growth at the most contaminated soil of the model experiment, whereas biochar application into the soil promoted the successful formation of the corn. The used biochar showed a high sorption capacity and its effectiveness under the soil remediation contaminated with $\mathrm{BaP}$.
\end{abstract}

Keywords: Carbon sorbent, vegetation experiment, remediation of soil, plant uptake, PAHs.

(C) 2021 Federation of Eurasian Soil Science Societies. All rights reserved

\section{Introduction}

Benzo[a]pyrene (BaP) is one of the most dangerous organic contaminants in the environment and the most toxic, carcinogenic, and mutagenic representatives of the polycyclic aromatic hydrocarbons (PAHs), firstclass dangerous compound (Tobiszewski and Namieśnik, 2012; IARC, 2020; Abdel-Shafy and Mansour, 2016). Its background content in Haplic Chernozems varies at the level of $15-25 \mu \mathrm{g} \mathrm{kg}-1$, which is due to the increased content of highly condensed organic matter in the Chernozems soil and its soil microflora specific composition (Sushkova et al., 2017). Absorbing on the soil surface as a pollutant the BaP is involved in the

https://doi.org/10.18393/ejss.935397

http://ejss.fesss.org/10.18393/ejss.935397
Publisher e-ISSN : 2147-4249 
processes of distribution in the soil-plant system (Tsibart and Gennadiev, 2013). Plants are an integral component of terrestrial ecosystems and are exposed to the entire group of pollutants, and almost $45 \%$ of all PAHs released into the environment uptake in plants (Kang et al., 2010). The complex of soil - plants interaction is an important object of environmental pollution control by BaP. Since soils and plants function in close relationship with each other, a whole system arises that connects the processes of accumulation and transformation of BaP in soils and plants (Li et al., 2015).

Currently, there are no full-fledged investigations of the mechanisms of the BaP uptake by plants, especially, connected with reducing BaP bioavailability to plants. BaP can sorb on the root cell walls, for example, which is reported by Pretorius (2018). BaP sorption processes proceed according to the lipophilicity of the compound molecule (Kang et al., 2010). It is noted that BaP diffusion into the plant root is very slow (Li et al., 2015). It has been shown that the BaP content in cereals could exceed $1 \mu \mathrm{g} \mathrm{kg}^{-1}$ ( $\mathrm{Li}$ et al, 2016; Liu et al, 2017; Tian et al., 2018). This process can relate to the level of soil contamination by the toxicant ( $\mathrm{Ni}$ at al., 2017; Chen et al., 2019). Also, it was established that the plant species have a different tolerance to $\mathrm{BaP}$ contamination. For example, cereal plants are capable to accumulate BaP up to $30-40 \%$ of their total content in the soil (Roszko et al., 2020). Thus, the assessment of soil toxicity to different species of plants is complicated by the pollutant's uptake selectivity (Ni et al., 2017). The same level of BaP contamination led to the different degree of soil toxicity for each agricultural crop (Iljina et al, 2020). Thus, the costs of reclamation of such soils can be unjustifiably overestimated or, conversely, underestimated, which increases the relevance of research in this direction (Kuppusamy et al., 2017; Li et al., 2020).

There are several sorbents that can be used for soil remediation under polyaromatic hydrocarbons contamination (Carvalho et al., 2015). This soil remediation technology is not only low-cost, easy to use, but highly effective both in terms of selective removal of pollutants and in terms of restoring soil quality (Lima, 2018). Carbon sorbents, such as biochar, are the most often used for soil remediation (Vardhan et al., 2019; Kołtowski et al., 2017). The global production of biochar alone reaches hundreds of thousand tons per year (Eeshwarasinghe et al., 2019). Biochar is characterized by a large specific pore surface area, and high stability in soil (Qin et al., 2013; Huggins et al., 2016; Liu et al., 2017; Yakovleva et al., 2017).

The purpose of this research was to establish the reduced spring barley (Hordeum Sativum) plant uptake of PAHs from soil amended with biochar in the artificially contaminated Haplic Chernozem. The mechanisms of $\mathrm{BaP}$ uptake will be determined for spring barley as the most common agricultural plant in the Chernozem distribution area. Thus, this model experiment will provide unique information about the consequences of technogenic contamination in the Chernozem zone of the South of Russia that will help to correctly choose the ways of remediation and cultivating the agricultural crops in this region.

\section{Material and Methods}

\section{Model experiment design}

A model laboratory experiment was laid to study the biochar effect on the PAHs uptake by spring barley (Hordeum Sativum). The soil $(0-20 \mathrm{~cm})$ of the specially protected natural area "Persianovskyi Preserve Steppe" was used sampled from the territory located at the Rostov Region, southern Russia (Figure 1), which is represented by Haplic Chernozem (Table 1). Haplic Chernozem soils occupy a significant area in the large agro-industrial regions of southern Russia, such as the Rostov Region and Krasnodar Krai territory.

Table 1. Physical and chemical properties of Haplic Chernozem $(0-20 \mathrm{~cm})$

\begin{tabular}{ccccccc}
\hline $\begin{array}{c}\text { Silt particles } \\
(<\mathbf{0 . 0 2} \mathbf{~ m m}), \mathbf{\%}\end{array}$ & $\begin{array}{c}\text { Clay particles } \\
(<\mathbf{0 . 0 0 2} \mathbf{~ m m}), \mathbf{\%}\end{array}$ & $\mathbf{C}_{\text {org. }} \mathbf{\%}$ & $\mathbf{p H}$ & $\mathbf{C a C O}_{\mathbf{3}}, \mathbf{\%}$ & $\begin{array}{c}\mathbf{C a}^{2+}+\mathbf{M g}^{2+}, \\
\mathbf{m m o l}(+\mathbf{+} / \mathbf{1 0 0 g}\end{array}$ & $\begin{array}{c}\mathbf{C E C}, \\
\mathbf{m m o l}(+\mathbf{+} / \mathbf{1 0 0} \mathbf{g}\end{array}$ \\
\hline $48.1 \pm 1.4^{*}$ & $28.6 \pm 1.2$ & $3.7 \pm 0.3$ & $7.3 \pm 0.1$ & $0.3 \pm 0.1$ & $35.0 \pm 3.0$ & $37.1 \pm 2.9$ \\
\hline
\end{tabular}

\pm the standard deviation (SD)

The selected soil was cleaned of plant residues and other inclusions, grounded in a porcelain mortar, and passed through a sieve with a hole diameter of $1 \mathrm{~mm}$. Air-dry soil $4 \mathrm{~kg}$ was placed in the vegetative vessels, and an aqueous solution of BaP in acetonitrile (400, 800 and $1200 \mu \mathrm{g} \mathrm{kg}^{-1}$ ) was added to the soil surface. The choice of doses of pollutants was determined by the existing levels of soil pollution in the Rostov Region (Sushkova et al., 2020). After the application of pollutants, the soil was incubated for 1 week, and then biochar was added in doses from $1 \%$ and $5 \%$ of the total soil volume.

The moisture content was maintained at $60 \%$ of the total field moisture capacity during the entire incubation period in the soil of the phytotoxicity model laboratory experiment (GOST RISO 22030-2009). 


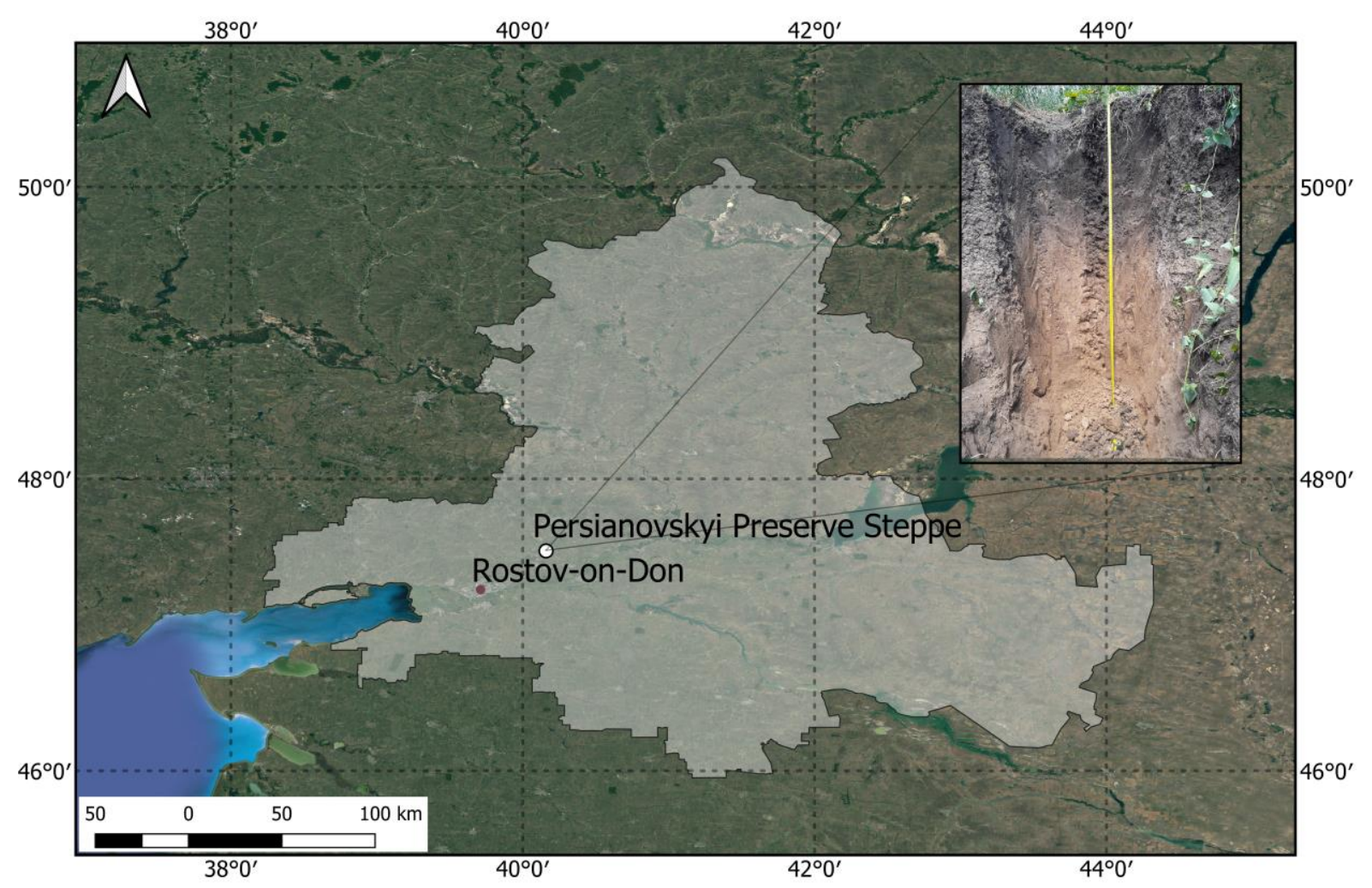

Figure 1. Soil sampling map.

After one month of incubating the soil with sorbents, the seeds of spring barley of the two-row variety Ratnik (Hordeum Sativum) of the Poaceae Family, which is one of the main grain crops grown in the Rostov region, were sown in the amount of 20 seeds per cup. Plants were sampled 3 months after sowing, and the PAHs content was measured in the soil, roots, stem, and corn of spring barley. The experiment was settled in 3 replications.

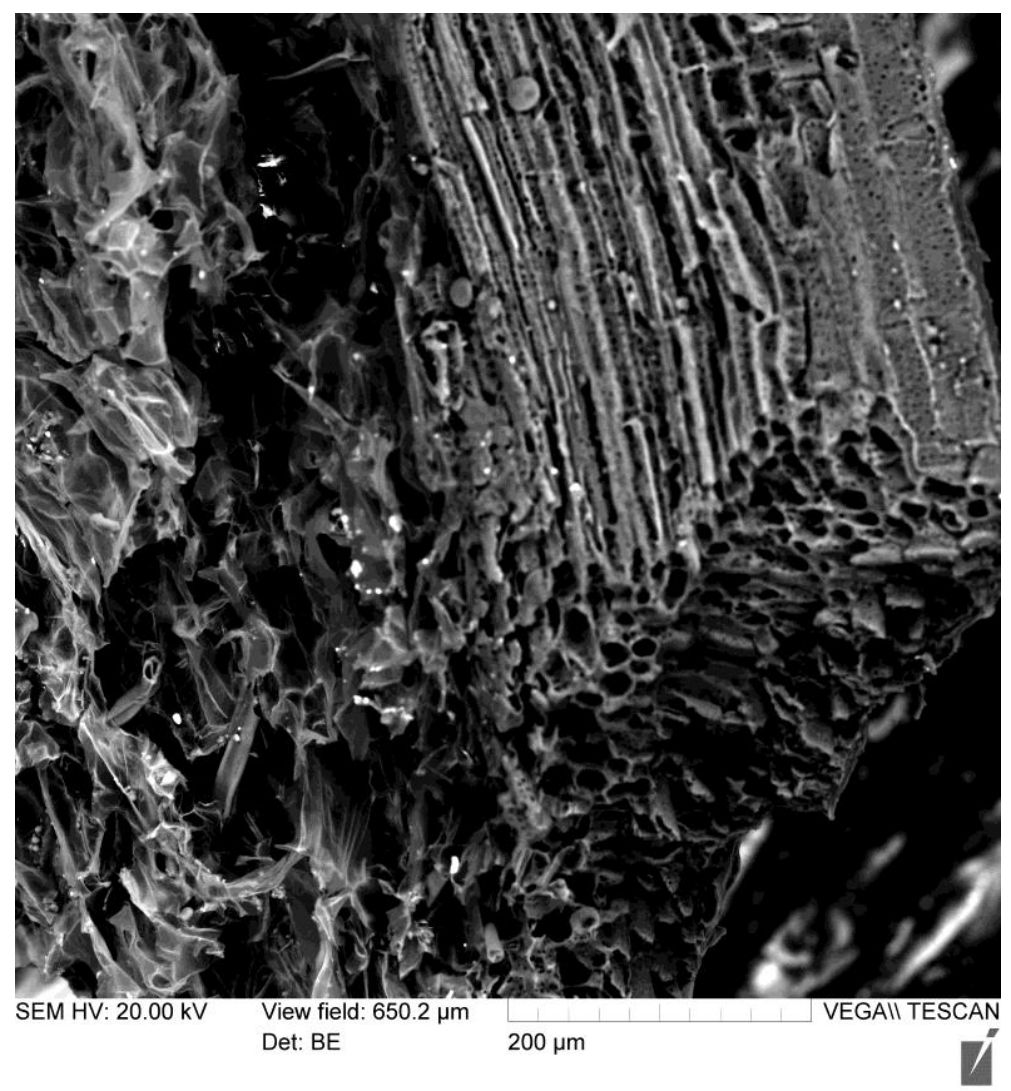

Figure 2. SEM image of the biochar from the regional sunflower husk.
Biochar made from sunflower husks at a pyrolysis temperature of $500^{\circ} \mathrm{C}$ was used for the model experiment. Scanning electron microscopy image of the biochar surface shows the various pores structure perspective for the PAHs adsorption from the soil (Figure 2). 


\section{Extraction of BaP from soil and plant samples}

$\mathrm{BaP}$ was extracted from soils and plants using the method of subcritical water extraction (Sushkova et al., 2016). A 1 g weighed portion of soil/plants (roots, stem, corn) was placed in an extraction cartridge, and 8 $\mathrm{ml}$ of bidistilled water was added after it was tightly screwed on both sides with bolts. A pressure gauge with a built-in emergency pressure relief valve was connected to the cartridge so that the pressure inside the cartridge was equal 55-60 atm. The cartridge was installed in a thermostat and heated to $250^{\circ} \mathrm{C}$ for $30 \mathrm{~min}$. After cooling the system, the cartridge was unscrewed, the contents were filtered 3 times through a paper filter with a blue ribbon into a glass conical flask to a clear solution, each time rinsing the filter with $2 \mathrm{ml}$ of distilled water. From the resulting aqueous extract, BaP was re-extracted three times with n-hexane (analytical grade). For that purpose, the $5 \mathrm{ml}$ of hexane was poured into the flask, closed with a glass stopper, and shaken on a shaker for 15 minutes. Separation of layers was carried out on a $50 \mathrm{ml}$ separating funnel sequentially in three stages with the next portion of hexane. The combined hexane extract was passed through a funnel with calcined anhydrous sodium sulfate, after which the extract was evaporated in a pearshaped flask on a rotary evaporator at a water bath temperature of $40^{\circ} \mathrm{C}$ to a dry residue. The resulting residue was dissolved in $1 \mathrm{ml}$ of acetonitrile with stirring for 30 minutes, and the concentration of $\mathrm{BaP}$ in the extract was determined by HPLC. The completeness of BaP extraction was determined by the addition method, for which a soil sample of $1 \mathrm{~g}$ was placed in a flask for a rotary evaporator and a certain amount of a standard $\mathrm{BaP}$ solution in acetonitrile was added based on the creation of a $\mathrm{BaP}$ concentration in the sample of $2,4,6,8,16$, or $32 \mu \mathrm{g} \mathrm{kg}-1$. After evaporation of the solvent for $30 \mathrm{~min}$ under room conditions, the analyte was kept at $7^{\circ} \mathrm{C}$ for 24 hours, and then the samples were analyzed by a high-performance liquid chromatography (HPLC) according to the certified procedures (MUK 4.1.1274-03. 4.1; ISO 13877-2005) using the system with fluorometric detection 1260 Infinity Agilent (USA).

The PAHs content was determined by the standardized external method (Procedure of measurements ..., 2008). The following equation was used to express the PAH's content:

$\mathrm{C}_{\mathrm{s}}=\mathrm{k} \mathrm{S}_{\mathrm{i}} \times \mathrm{C}_{\mathrm{st}} \times \mathrm{V} /\left(\mathrm{S}_{\mathrm{st}} \times \mathrm{m}\right)$,

where $\mathrm{C}_{s}$ and $\mathrm{C}_{\mathrm{st}}$ are the PAH concentrations determined in the soil sample and the standard PAH solution, respectively $(\mu \mathrm{g} \mathrm{kg}-1) . S_{\text {st }}$ and $S_{\mathrm{i}}$ correspond to areas under the peak of PAH standard solution, and studied sample, respectively. $\mathrm{V}, \mathrm{k}$, and $\mathrm{m}$ are assigned to the acetonitrile volume used for extraction ( $\mathrm{mL}$ ), the recovery factor for PAH from the sample and the mass sample (g), respectively. The efficiency of target PAHs extraction from soils was calculated using a spike matrix.

Samples were analyzed for 16 PAHs (naphthalene; chrysene; phenanthrene; benzo[k]fluoranthene; anthracene; a cenaphthylene; pyrene; fluoranthene; biphenyl; benzo[a]anthracene; benzo[b]fluoranthene; acenaphthene; benzo[a]pyrene; dibenzo[a,h]anthracene; fluorine; benzo[g,h,i]perylene) with an Agilent 1260 (Germany) Infinity high-performance liquid chromatography (HPLC) equipped with a fluorescence detector following the ISO 13859:2014 requirements. The HPLC system was coupled to reversed-phase column Hypersil BDS C18 $(150 \times 4.6 \mathrm{~mm}, 5 \mu \mathrm{m})$ with a mixture of acetonitrile and ultrapure water as the mobile phase. Compounds were identified according to the retention time recorded by the corresponding analytical standard samples. HPLC grade acetonitrile (99.9\%, analytical grade), anhydrous $\mathrm{Na}_{2} \mathrm{SO}_{4}$, n-hexane (99\%, analytical grade), ethanol (96\%, analytical grade), potassium hydrate (98\%, analytical grade), and $\mathrm{NaOH}$ (97\%, analytical grade), were used in the analysis. All research results were performed in 3-fold analytical replication.

\section{Statistical analysis of the results}

SigmaPlot 12.5 and Statistica 10 were used for processing data. The reliability of differences between the experimental variants was assessed using the Student's t-test, with a fixed p-level $<0.05$. The relationships between the variables were estimated using linear regression with a fixed $\mathrm{p}$-level $<0.001$.

\section{Results and Discussion}

\section{BaP content in the soil of the model experiment}

After 4 months of model experiment contamination, it has been established that contamination leads to $\mathrm{BaP}$ and priority PAHs accumulation in the soil of the model experiment (Figure 3). The content of BaP in Persianovskyi Preserve Steppe as control soil amounted to $17.6 \pm 0.7 \mu \mathrm{g} \mathrm{kg}^{-1}$ that is lower MPC (GN 2.1.7.2041-06. 2.1.7, 2006), total PAHs content was at the level $230.5 \pm 11.1 \mu \mathrm{g} \mathrm{kg}-1$ that corresponds to our previous research data (Sushkova et al., 2017; Sushkova et al., 2020). BaP content in soil contaminated with doses of $400 \mu \mathrm{g} \mathrm{kg}-1,800 \mu \mathrm{g} \mathrm{kg}^{-1}$ and $1200 \mu \mathrm{g} \mathrm{kg}-1$ promoted an increase of the BaP content in the soil to 
$355.6 \pm 13.3 \mu \mathrm{g} \mathrm{kg}-1,620.1 \pm 32.2 \mu \mathrm{g} \mathrm{kg}^{-1}$ and $870.1 \pm 44.3 \mu \mathrm{g} \mathrm{kg}-1$, respectively, as well, it was established a total PAHs content increasing in the BaP contaminated soil up to $660.9 \pm 31.7 \mu \mathrm{g} \mathrm{kg}^{-1}, 1154.5 \pm 58.3 \mu \mathrm{g} \mathrm{kg}^{-1}$ and $1350.7 \pm 68.9 \mu \mathrm{g} \mathrm{kg}^{-1}$, respectively.

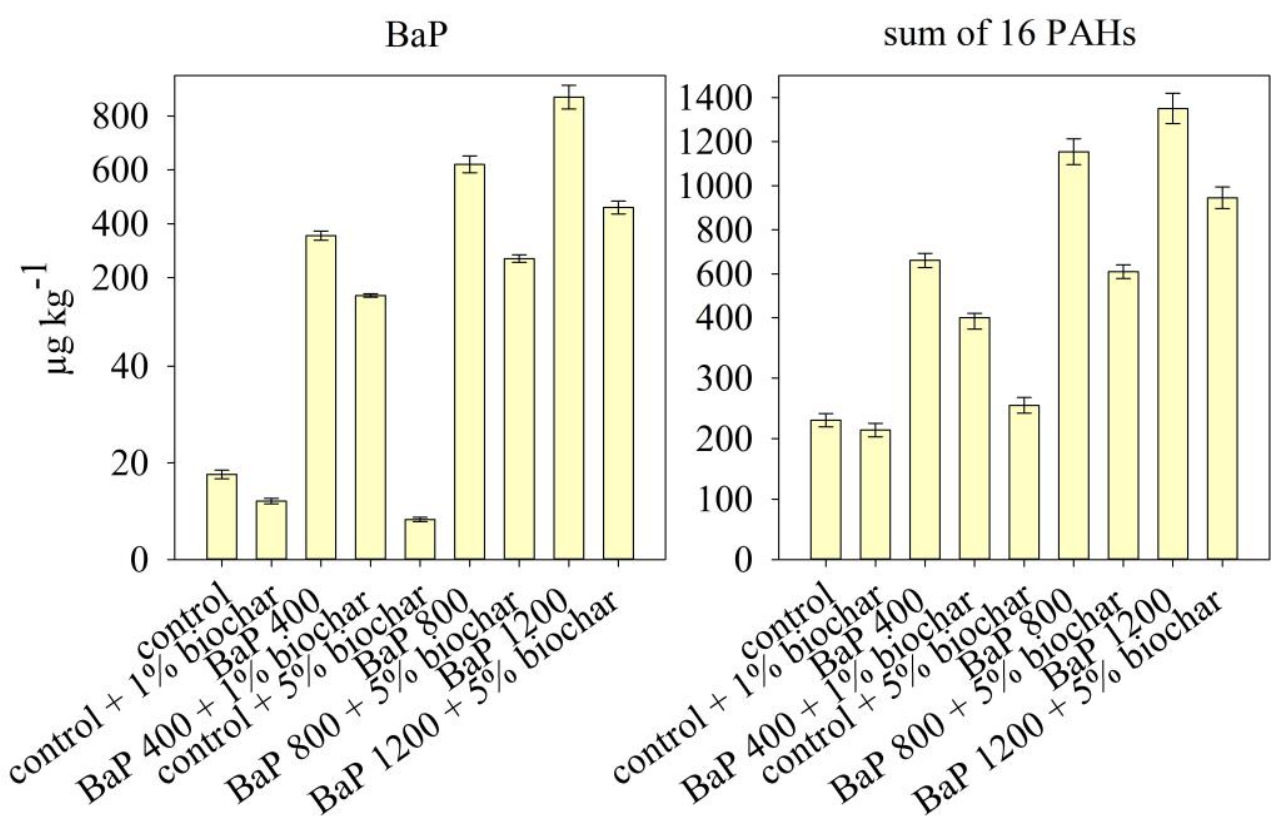

Experience options

Figure 3. Benzo[a]pyrene and sum of total PAHs content in the soil of model vegetation experiment

The biochar application doses were divided to the pollution level and chose as $1 \%$ of the mass volume for variants with uncontaminated control soil and soil contaminated by $400 \mu \mathrm{g} \mathrm{kg}^{-1} \mathrm{BaP}$. The close relations were found by Vasilyeva et al. (2020). The biochar $5 \%$ was applied in the soil contaminated with $800 \mu \mathrm{gg}^{-1}$ $\mathrm{BaP}$ and $1200 \mu \mathrm{g} \mathrm{kg}^{-1} \mathrm{BaP}$. Biochar 1\% amendment to soil decreased BaP content in control soil to 31\%, and $5 \%$ biochar application decreased BaP content to 53\%, compared to control, whereas the total PAHs content did not show any representative changes in its content under the biochar application. As well as $5 \%$ biochar application led to $10 \%$ increasing of the total PAHs content in the control soil which is most probably caused by pyrogenic PAHs presence in the biochar structure forming during the pyrolysis process (Hale et al., 2011).

The application of biochar at a dose of $1 \%$ into the soil contaminated with $400 \mu \mathrm{g} \mathrm{kg}^{-1} \mathrm{BaP}$ was accompanied by a decrease in the $\mathrm{BaP}$ content up to $62.5 \%$ and in the total PAHs content up to $39 \%$. In the variant contaminated with $800 \mu \mathrm{g} \mathrm{kg}^{-1} \mathrm{BaP}$ the application of $5 \%$ of biochar led to the BaP content decreasing up to $56 \%$ from its initial content in the soil, and total PAHs content decreased to $47 \%$. Application of 5\% biochar in the soil contaminated by $1200 \mu \mathrm{g} \mathrm{kg}-1$ BaP effect on the BaP and total PAHs content decreasing to $47 \%$ and $30 \%$, respectively. The data received associated with the study reported by Bonaglia et al. (2020), shows a possibility of polyaromatic hydrocarbons microbial degradation under the biochar application in the petroleum-contaminated soil. Chen and Chen (2009) estimated the perspectives of biochar using for some PAHs sorption that approves the biochar efficiency using for the PAHs contaminated soil remediation.

\section{BaP content in the plants of the model experiment}

The $\mathrm{BaP}$ and total PAHs content were determined for all parts of the spring barley plants, such as roots, stem, and corn. Since BaP has a toxic effect, barley plants have not reached the heading stage in the variant contaminated with $1200 \mu \mathrm{g} \mathrm{kg}^{-1}$. Soil contamination by BaP showed the spring barley uptake as BaP, as total PAHs from the soil.

$\mathrm{BaP}$ accumulation in roots of control plants was $0.9 \pm 0.1 \mu \mathrm{g} \mathrm{kg}-1$, total PAHs content was at the level $105.4 \pm 4.3 \mu \mathrm{g} \mathrm{kg}^{-1}$; for stem the BaP content was $0.4 \pm 0.03 \mu \mathrm{g} \mathrm{kg}^{-1}$, total PAHs content was $40.9 \pm 2.5 \mu \mathrm{g} \mathrm{kg}^{-1}$; for corn BaP content estimated at the level $0.1 \pm 0.02 \mu \mathrm{g} \mathrm{kg}-1$, total PAHs content was $15.5 \pm 1.6 \mu \mathrm{g} \mathrm{kg}^{-1}$ (Figure 4). Contamination with $400 \mu \mathrm{g} \mathrm{kg}^{-1} \mathrm{BaP}$ showed an increased BaP and total PAHs content in the spring barley roots $115.2 \pm 6.0 \mu \mathrm{g} \mathrm{kg}^{-1}$, total PAHs content was at the level $291.6 \pm 14.0 \mu \mathrm{g} \mathrm{kg}{ }^{-1}$; in stem BaP content increased up to $36.0 \pm 1.7 \mu \mathrm{gg}^{-1}$, total PAHs content was at the level $106.3 \pm 5.0 \mu \mathrm{g} \mathrm{kg}-1$; in corn BaP content was $12.6 \pm 0.6 \mu \mathrm{g} \mathrm{kg}^{-1}$, total PAHs content estimated as $54.3 \pm 2.6 \mu \mathrm{g} \mathrm{kg}^{-1}$. The data received corresponding to the data Manzetti (2013). 


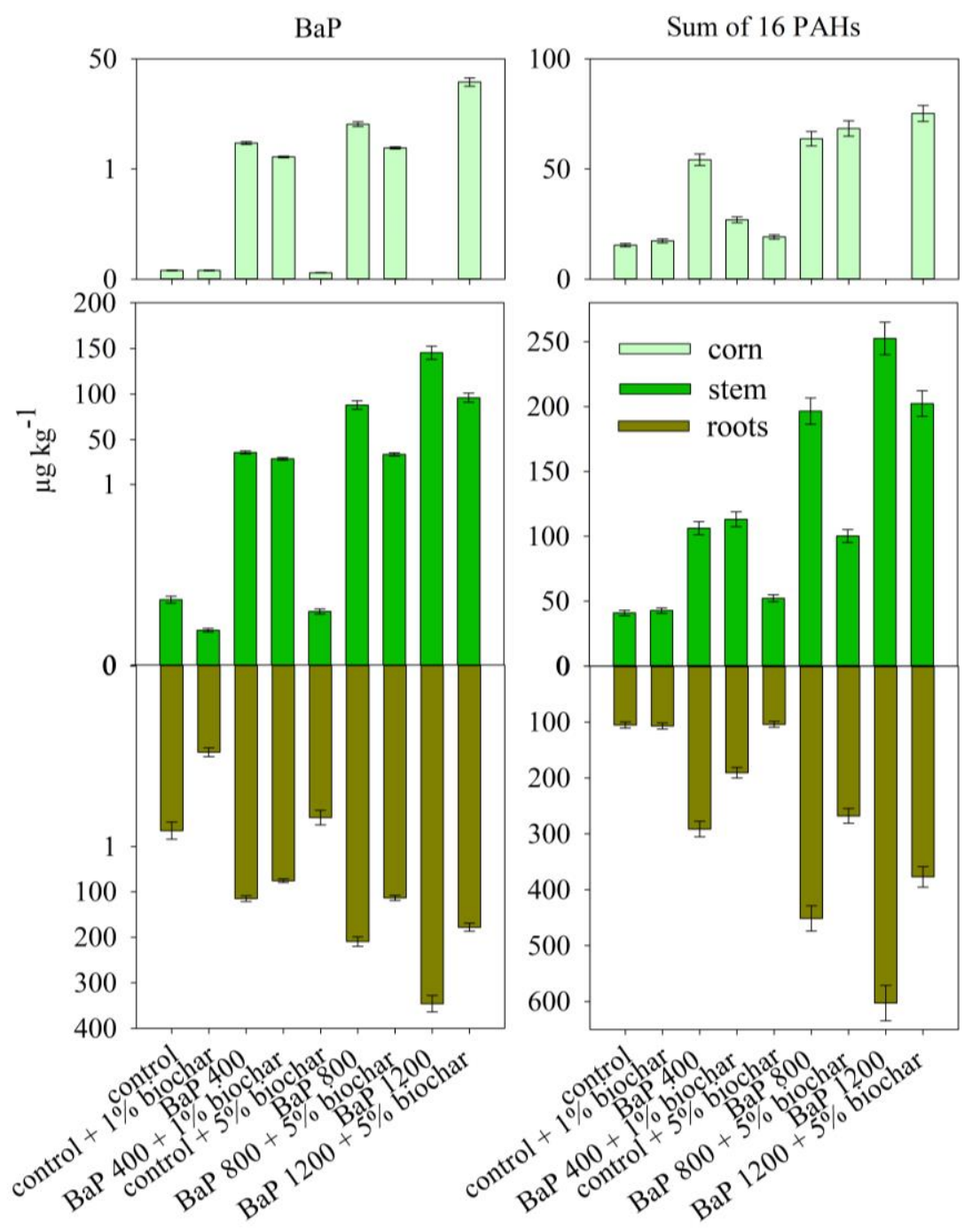

Experience options

Figure 4. Benzo[a]pyrene and sum of total PAHs content in the roots, stem and corn of spring barley plants of model vegetation experiment.

Biochar $1 \%$ application in the control uncontaminated soil led to the BaP decreasing in the spring barley roots and stem up to 50\% compared to control, in the corn there was no difference. Applying the 5\% of biochar did not affect the BaP and total PAHs content in plants.

It was found the $1 \%$ biochar application in the variant contaminated with $400 \mu \mathrm{gg}^{-1} \mathrm{BaP}$ affected the toxicant uptake by spring barley plant. BaP content in roots, as well as total PAHs content decreased up to $34 \%$ compared to contaminated variant, in stem there was found 19\% decreasing of BaP content and in corn the content of $\mathrm{BaP}$ and PAHs decreased to $50 \%$, that shows a high effectiveness of biochar application in the above-mentioned dose (Figure 5).

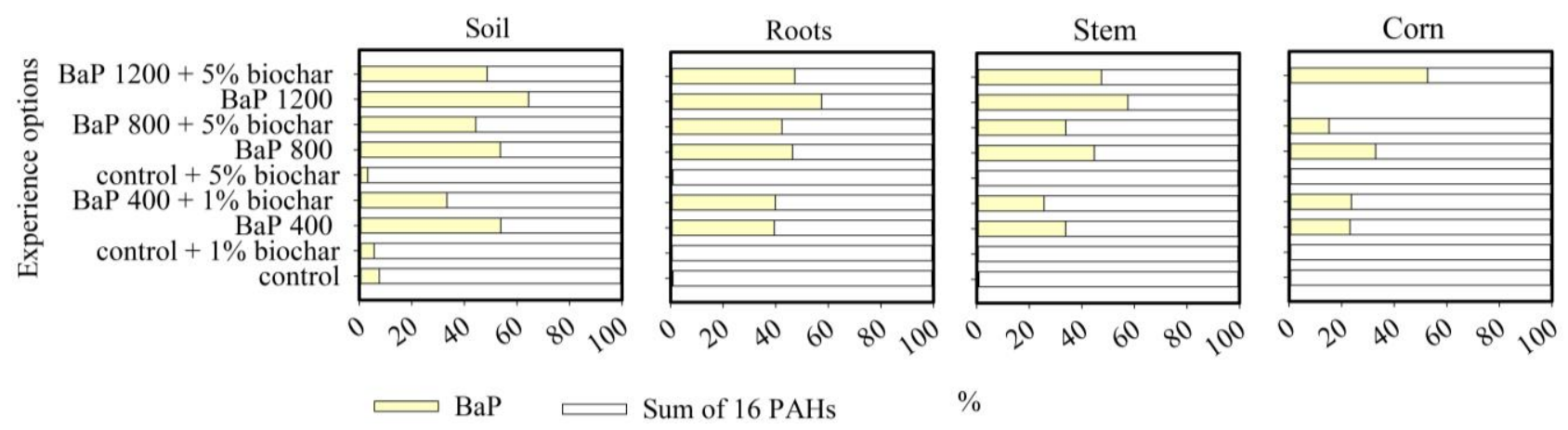

Figure 5. Benzo[a]pyrene to total PAHs content \% relation in the different parts of spring barley plants and contaminated soil. 
Soil contamination with $800 \mu \mathrm{g} \mathrm{kg}-1$ BaP led to an intensive BaP and total PAHs uptake by the spring barley roots $209.4 \pm 10.5 \mu \mathrm{g} \mathrm{kg}^{-1}$, total PAHs content was at the level $451.4 \pm 22.6 \mu \mathrm{g} \mathrm{kg}^{-1}$; in stem BaP content increased up to $88.0 \pm 4.6 \mu \mathrm{g} \mathrm{kg}^{-1}$, total PAHs content was at the level $196.5 \pm 10.2 \mu \mathrm{g} \mathrm{kg}^{-1}$; in corn BaP content was $21.0 \pm 1.1 \mu \mathrm{g} \mathrm{kg}^{-1}$, total PAHs content estimated as $63.7 \pm 3.3 \mu \mathrm{g} \mathrm{kg}-1$.

In the variant contaminated with $800 \mu \mathrm{g} \mathrm{kg}-1$ BaP the application of $5 \%$ of biochar led to the BaP and total PAHs content decreasing in roots up to $40-46 \%$ from the plants of contaminated variant. In stem there was established $\mathrm{BaP}$ and total PAHs content decreasing up to $49-61 \%$, and in corn only BaP content decreased up to $49 \%$.

$\mathrm{BaP}$ application in the soil in amount of $1200 \mu \mathrm{g} \mathrm{kg}{ }^{-1} \mathrm{BaP}$ showed the extremely high level of toxicant uptake by plants. The content of BaP and total PAHs in roots was $346.0 \pm 18.2 \mu \mathrm{g} \mathrm{kg}^{-1}$, and $602.9 \pm 31.7 \mu \mathrm{g} \mathrm{kg}^{-1}$, respectively. For stem this level were found at the level $145.3 \pm 7.1 \mu \mathrm{g} \mathrm{kg}^{-1}$, and $252.5 \pm 12.5 \mu \mathrm{g} \mathrm{kg}^{-1}$, respectively. Corn is this variant didn't form that is connected with a high BaP toxicity for this contamination level.

Biochar amendment $5 \%$ showed a high effectiveness, because on the variant $1200 \mu \mathrm{gg}^{-1} \mathrm{BaP}+$ biochar $5 \%$ the corn successfully formed. BaP and total PAHs content decreased in roots up to $37-48 \%$ from the plants of contaminated variant. In stem there was established BaP and total PAHs content decreasing up to 19-33\%.

The differences in the BaP uptake by spring barley plants can be described by their relations roots/soil, stem/roots and stem/corn (Iljina et al., 2020). In all contaminated variants there was found a gradual decreasing of the bioaccumulation coefficients after biochar application that shows an improvement of plant barrier mechanisms to $\mathrm{BaP}$ and total PAHs content during the remediation process using $1 \%$ and $5 \%$ of biochar under the different contamination level (Figure 6).

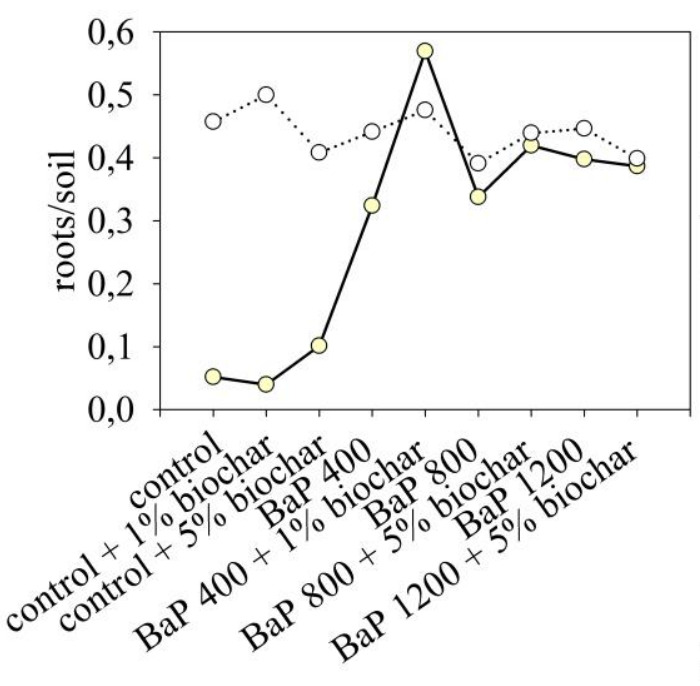

Experience options
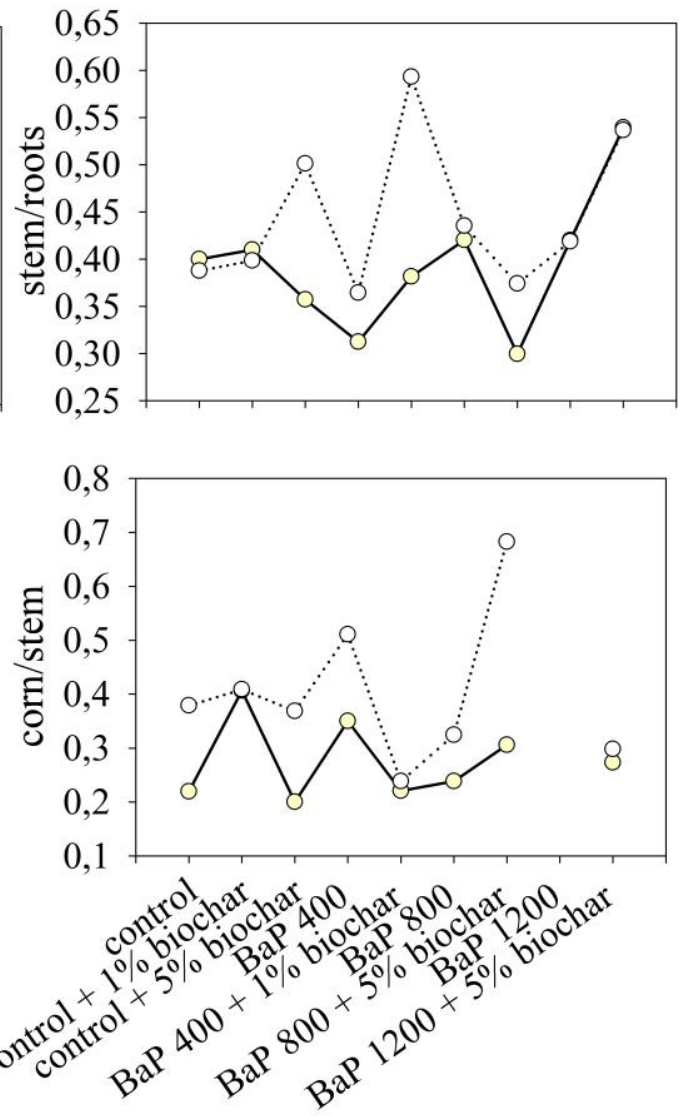

Experience options

Figure 6. Bioaccumulation coefficients of benzo[a]pyrene and sum of total PAHs for soil and different parts of spring barley.

\section{Conclusion}

Thus, it was found that the soil contamination with a concentration of 400, 800 and $1200 \mu \mathrm{gg}^{-1} \mathrm{contributed}$ to the $\mathrm{BaP}$ and total PAHs accumulation in soil and all plants. All contaminated doses promoted the inhibition in the growth characteristics of plants. The effect intensified with an increase in the pollutant 
concentration. The highest degree inhibition of the spring barley has been observed at the variant with $\mathrm{BaP}$ application $1200 \mu \mathrm{g} \mathrm{kg}-1$.

It was studied the optimal doses of biochar application for the soil remediation under the high and ultrahigh levels of BaP contamination for decreasing of the plants uptake. The dose of sorbent application was $1 \%$ for soil contamination with $\mathrm{BaP}$ in concentration $400 \mu \mathrm{g} \mathrm{kg}-1$. The BaP level decreased in soil and plants up to $50 \%$ compared to the contaminated variant. In soil contaminated with $800 \mu \mathrm{g} \mathrm{kg}^{-1}$ the dose $5 \%$ of biochar contributed to the $\mathrm{BaP}$ content decreasing in the soil and plants up to $60 \%$. Application of $5 \%$ biochar in the soil contaminated by $1200 \mu \mathrm{gg}^{-1}$ effected on the PAHs content decreasing up to $47 \%$ that shows a high sorption capacity of biochar and its effectiveness under the soil remediation process.

\section{Acknowledgement}

The study was carried out with the financial support of the Russian Science Foundation, project No. 19-7410046.

\section{References}

Abdel-Shafy, H.I., Mansour, M.S.M., 2016. A review on polycyclic aromatic hydrocarbons: Source, environmental impact, effect on human health and remediation. Egyptian Journal of Petroleum 25 (1): 107-123.

Bonaglia, S., Broman, E., Brindefalk, B., Hedlund, E., Hjorth, T., Rolff, C., Nascimento, F.J.A., Udekwu, K., Gunnarsson, J.S., 2020. Activated carbon stimulates microbial diversity and PAH biodegradation under anaerobic conditions in oil-polluted sediments. Chemosphere 248: 126023.

Carvalho, M.M., Vila, M.C., Delerue-Matos, C.C., Oliva-Teles, M.T., Fiúza, A.T., 2015. Assisted bioremediation tests on three natural soils contaminated with benzene. Eurasian Journal of Soil Science 4 (3): 153-160.

Chen, B., Chen, Z., 2009. Sorption of naphthalene and 1-naphthol by biochars of orange peels with different pyrolytic temperatures. Chemosphere 76 (1): 127-133.

Chen, J., Xia, X., Wang, H., Zhai, Y., Xi, N., Lin, H., Wen, W., 2019. Uptake pathway and accumulation of polycyclic aromatic hydrocarbons in spinach affected by warming in enclosed soil/water-air-plant microcosms. Journal of Hazardous Materials 379: 120831.

Eeshwarasinghe, D., Loganathan, P., Kalaruban, M., Sounthararajah, D. P., Kandasamy, J., Vigneswaran, S., 2018. Removing polycyclic aromatic hydrocarbons from water using granular activated carbon: kinetic and equilibrium adsorption studies. Environmental Science and Pollution Research 25 (14): 13511-13524.

GN 2.1.7.2041-06. 2.1.7., 2006. Maximum allowable concentration (MPC) of chemicals in the soil: Hygienic standards, Moscow, Russia. 15p.

GOST RISO 22030-2009, 2009. National standard of Russian Federation. Soil quality. Biological methods. Chronic phytotoxicity for higher plants, Moscow, Russia. 20p.

Hale, S., Hanley, K., Lehmann, J., Zimmerman, A., Cornelissen, G., 2011. Effects of chemical, biological, and physical aging as well as soil addition on the sorption of pyrene to activated carbon and biochar. Environmental Science \& Technology 45 (24): 10445-10453.

Huggins, T.M., Haeger, A., Biffinger, J.C., Ren, Z.J., 2016. Granular biochar compared with activated carbon for wastewater treatment and resource recovery. Water Research 94: 225-232.

IARC, 2020. List of classifications, volumes 1-123. IARC Monographs on the Evaluation of Carcinogenic Risks to Humans. International Agency for Research on Cancer, World Health Oorganization. Available at [Access date: 25.07.2020]: https://monographs.iarc.who.int/list-of-classifications/

Iljina, L., Rajput, V., Mazarji, M., Chernikova, N., Gülser, C., Kızılkaya, R., Nevidomskaya, D., Barahov, A., Sushkova, S., Minkina, T., Mandzhieva, S., Chaplygin, V., 2020. Accumulating capacity of herbaceous plants of the Asteraceae and Poaceae families under technogenic soil pollution with zinc and cadmium. Eurasian Journal of Soil Science 9 (2): $165-172$.

ISO 13877-2005, 2005. Soil Quality - Determination of Polynuclear Aromatic Hydrocarbons - Method Using Highperformance Liquid Chromatography. 20p.

Kang, F., Chen, D., Gao, Y., Zhang, Y., 2010. Distribution of polycyclic aromatic hydrocarbons in subcellular root tissues of ryegrass (Lolium multiflorumLam.). BMC Plant Biology 10 (1): 210.

Kołtowski, M., Hilber, I., Bucheli, T.D., Charmas, B., Skubiszewska-Zięba, J., Oleszczuk, P., 2017. Activated biochars reduce the exposure of polycyclic aromatic hydrocarbons in industrially contaminated soils. Chemical Engineering Journal 310: 33-40.

Kuppusamy, S., Thavamani, P., Venkateswarlu, K., Lee, Y. B., Naidu, R., Megharaj, M., 2017 Remediation approaches for polycyclic aromatic hydrocarbons (PAHs) contaminated soils: Technological constraints, emerging trends and future directions. Chemosphere 168: 944-968.

Li, H., Ma, Y., 2016. Field study on the uptake, accumulation, translocation and risk assessment of PAHs in a soil-wheat system with amendments of sewage sludge. Science of the Total Environment 560-561: 55-61.

Li, R., Zhu, Y., Zhang, Y., 2015. In situ investigation of the mechanisms of the transport to tissues of polycyclic aromatic hydrocarbons adsorbed onto the root surface of Kandelia obovata seedlings. Environmental Pollution 201: 100106. 
Li, F., Chen, J., Hu, X., He, F., Bean, E., Tsang, D.C., Ok, Y.S., Gao, B., 2020. Applications of carbonaceous adsorbents in the remediation of polycyclic aromatic hydrocarbon-contaminated sediments: A review. Journal of Cleaner Production 255: 120263.

Lima, E.C., 2018. Removal of emerging contaminants from the environment by adsorption. Ecotoxicology and Environmental Safety 150: 1-17.

Liu, W., Wang, Y., Chen, Y., Tao, S., Liu, W., 2017. Polycyclic aromatic hydrocarbons in ambient air, surface soil and wheat grain near a large steel-smelting manufacturer in northern China. Journal of Environmental Sciences 57: 93-103.

Manzetti, S., 2013. Polycyclic aromatic hydrocarbons in the environment: environmental fate and transformation. Polycyclic Aromatic Compounds 33 (4): 311-330.

MUK 4.1.1274-03. 4.1., 2003. Control methods. Chemical factors. Measurement of the mass fraction of benzo (a) pyrene in samples of soils, grounds, bottom sediments and solid waste by HPLC using a fluorometric detector. Methodological guidelines (approved by the Ministry of Health of Russia on 01.04.2003) // Measurement of the mass concentration of chemicals by luminescent methods in environmental objects: Collection of guidelines, Moscow, Russia. 244-267p. [in Russian].

Ni, N., Song, Y., Shi, R., Liu, Z., Bian, Y., Wang, F., Yang, X., Gu, C., Jiang, X., 2017. Biochar reduces the bioaccumulation of PAHs from soil to carrot (Daucus carota L.) in the rhizosphere: A mechanism study. Science of the Total Environment 601: 1015-1023.

Pretorius, T.R., Charest, C., Kimpe, L.E., Blais, J.M., 2018. The accumulation of metals, PAHs and alkyl PAHs in the roots of Echinacea purpurea. PloS One 13 (12): 1-18.

Qin, G., Gong, D., Fan, M.Y., 2013. Bioremediation of petroleum-contaminated soil by biostimulation amended with biochar. International Biodeterioration \& Biodegradation 85: 150-155.

Procedure of measurements benzo(a)pyrene content in soils, sediments and sludges by highly effective liquid chromatography method, 2008. Certificate 27-08: Moscow. 27p. [in Russian].

Roszko, M.Ł., Juszczyk, K., Szczepańska, M., Świder, O., Szymczyk, K., 2020. Background levels of polycyclic aromatic hydrocarbons and legacy organochlorine pesticides in wheat sampled in 2017 and 2018 in Poland. Environmental Monitoring and Assessment 192 (2): 142.

Sushkova, S.N., Minkina, T.M., Mandzhieva, S.S., Vasilyeva, G.K., Borisenko, N.I., Turina, I.G., Bolotova, O.V., Varduni T.V., Kızılkaya, R., 2016. New alternative method of benzo[a]pyrene extractionfrom soils and its approbation in soil under technogenic pressure. Journal of Soils and Sediments 16 (4): 1323-1329.

Sushkova, S., Minkina, T., Deryabkina, I., Antonenko, E., Mandzhieva, S., Zamulina, I., Bauer, T., Gromakova, N., Vasilyeva, G., 2017. Phytoaccumulation of Benzo[a]pyrene by the barley in artificially contaminated soil. Polycyclic Aromatic Compounds 39(5): 395-403.

Sushkova, S., Minkina, T., Tarigholizadeh, S., Antonenko, E., Konstantinova, E., Gülser, C., Dudnikova, T., Barbashev, A., Kızılkaya, R., 2020. PAHs accumulation in soil-plant system of Phragmites australis Cav. in soil under long-term chemical contamination. Eurasian Journal of Soil Science 9 (3): 242-253.

Tian, K., Bao, H., Zhang, X., Shi, T., Liu, X., Wu, F., 2018. Residuals, bioaccessibility and health risk assessment of PAHs in winter wheat grains from areas influenced by coal combustion in China. Science of The Total Environment 618: 777-784.

Tobiszewski, M., Namieśnik, J., 2012. PAH diagnostic ratios for the identification of pollution emission sources. Environmental Pollution 162: 110-119.

Tsibart, A.S., Gennadiev, A.N., 2013. Polycyclic aromatic hydrocarbons in soils: sources, behavior, and indication significance (a review). Eurasian Soil Science 46 (7): 728-741.

Vardhan, K.H., Kumar, P.S., Panda, R.C., 2019. A review on heavy metal pollution, toxicity and remedial measures: Current trends and future perspectives. Journal of Molecular Liquids 290: 111197.

Vasilyeva, G., Kondrashina, V., Strijakova, E., Ortega-Calvo, J.J., 2020. Adsorptive bioremediation of soil highly contaminated with crude oil. Science of the Total Environment 706: 135739.

Yakovleva, E.V., Gabov, D.N., Beznosikov, V.A., Kondratenok, B.M., Dubrovskiy, Y.A., 2017. Accumulation of PAHs in tundra plants and soils under the influence of coal mining. Polycyclic Aromatic Compounds 37 (2-3): 203-218. 